\title{
Effect of irrigating fluid temperature on core body temperature during Transurethral resection of the prostate
}

\author{
Taufan Tenggara, Djoko Rahardjo
}

\begin{abstract}
Abstrak
Tujuan penelitian ini adalah untuk melihat efek temperatur cairan irigasi terhadap perubahan temperatur inti badan selama prosedur Transurethral Resection of the Prostate (TURP). Suatu uji klinis acak terkontrol dilakukan terhadap 32 penderita pembesaran prostat jinak (Benign Prostatic Hyperplasia = BPH) yang menjalani prosedur TURP di RSUPNCM Jakarta, antara bulan September 2003 dan Januari 2004. Secara acak berselang-seling, penderita penelitian dimasukkan ke dalam kelompok standar (menggunakan cairan irigasi setara temperatur kamar $\pm 23.6^{\circ} \mathrm{C}$ ) dan kelompok isotermik (menggunakan cairan irigasi yang dihangatkan sampai setara dengan temperatur badan $+37.2^{\circ} \mathrm{C}$ ). Jenis cairan irigasi yang digunakan oleh kedua kelompok adalah aquabidest. Kemudian dilakukan pencatatan terhadap usia penderita, lama reseksi, berat jaringan prostat yang direseksi, volume total cairan irigasi yang digunakan, temperatur kamar operasi serta temperatur inti badan sebelum dan sesudah prosedur TURP. Uji hipotesis untuk kedua kelompok menggunakan uji t, dengan nilai $p<0,05$ dianggap bermakna. Hasil penelitian menunjukkan bahwa terdapat penurunan temperatur inti badan selama prosedur TURP, baik pada kelompok standar maupun pada kelompok isotermik (keduanya $p=0,000$ ), tetapi tidak satupun penderita dari kedua kelompok tersebut yang masuk dalam kriteria hipotermi. Rerata penurunan temperatur inti badan pada kelompok standar $\left(0,99^{\circ} \mathrm{C}\right)$ lebih besar dibandingkan dengan kelompok isotermik $\left(0,75^{\circ} \mathrm{C}\right)$, tetapi secara statistik tidak berbeda bermakna $(p>0,05)$. Dari penelitian ini dapat disimpulkan bahwa penggunaan cairan irigasi selama prosedur TURP baik dengan temperatur yang setara dengan temperatur badan maupun yang setara dengan temperatur kamar, sama-sama menyebabkan penurunan temperatur inti badan pada tingkat yang kurang lebih sama. (Med J Indones 2005; 14: 152-6)
\end{abstract}

\begin{abstract}
The objective of this study was to determine the effect of irrigating fluid temperature on core body temperature changes in patients undergoing transurethral resection of the prostate (TURP). A cross sectional study was conducted on 32 patients with Benign Prostatic Hyperplasia (BPH) who underwent TURP at our institution between September 2003 and January 2004. Patients were randomized to one of two groups. Standard group consisted of 16 patients who received room temperature irrigating fluid $\left( \pm 23.6^{\circ} \mathrm{C}\right)$ throughout TURP. Isothermic group consisted of 16 patients whose procedure was performed using warmed irrigating fluid $\left( \pm 37.2^{\circ} \mathrm{C}\right)$. The irrigating fluid used for both groups was aquabidest. The age, resection time, weight of resected prostate, amount of irrigating fluid used, temperature in the operating theatre, core body temperature at beginning and at conclusion of TURP were recorded for each patient. The $t$ test was used for comparison between both groups and a p value of 0.05 or less was considered significant. The result of this study showed a decrease of core body temperature during TURP, using either room temperature or warmed irrigating fluid (both $p=0.000$ ). None of the patients in either group demonstrated any criteria of hypothermia. The average decrease of core body temperature in standard group $\left(0.99^{\circ} \mathrm{C}\right)$ was greater than in isothermic group $\left(0.75^{\circ} \mathrm{C}\right)$, but it was not significantly different $(p>0.05)$. In conclusion, our study revealed that using either room temperature irrigating fluid or warmed irrigating fluid during TURP could decrease core body temperature at approximately similar level, with no incidence of hypothermia. (Med J Indones 2005; 14: 152-6)
\end{abstract}

Keywords: hypothermia, body temperature, irrigating fluid

Over the years, Transurethral Resection of the Prostate (TURP), as a treatment modality for obstructing Benign Prostatic Hyperplasia (BPH), gained popularity

Department of Urology, Faculty of Medicine, University of Indonesia, Jakarta, Indonesia throughout the world. It is now considered as the gold standard for the surgical management for $\mathrm{BPH} .{ }^{1}$

However, serious questions have been raised concerning the mortality and morbidity rates. The lowest reported mortality rate after TURP is $0.23 \%$, but in most recent studies the incidence is 0.5 to $1 \%{ }^{2}$ Immediate postoperative complications such as TUR 
syndrome, hemolysis, hemorrhage, infection and perforation, along with late complications such as retrograde ejaculation, incontinence, impotence, urethral stricture and bladder neck contracture have been reported to occur in up to $18 \%$ of all patients undergoing TURP. ${ }^{3}$

Postoperative hypothermia has been reported as another immediate complication after TURP and strongly correlates with cardiovascular risk factor, especially in older men. ${ }^{2}$ Several studies in the urologic literature have attributed this drop in core body temperature to the use of room temperature irrigating fluid. ${ }^{3}$

Until now, at the Department of Urology, Cipto Mangunkusumo National Central General Hospital Jakarta, we are still using aquabidest with room temperature as irrigating fluid during TURP and there is no postoperative hypothermia case reported.

The objective of this study was to determine the effect of irrigating fluid temperature on core body temperature changes in patients undergoing TURP in an attempt to evaluate the level of safety of using room temperature irrigating fluid during TURP.

\section{METHODS}

This is a prospective randomised trial, conducted between September 2003 and January 2004 on the patients with diagnosis of BPH, scheduled for TURP at our institution. Patients were randomly assigned to one of two groups. Standard group $(n=16)$ underwent TURP using room temperature irrigating fluid $\left( \pm 23{ }^{\circ} \mathrm{C}\right)$ and isothermic group $(n=16)$ received warmed irrigating fluid $\left( \pm 37{ }^{0} \mathrm{C}\right)$. The irrigating fluid for both groups was aquabidest.

All the patients in the study had their core body temperatures recorded on arrival to the operating theatre and just before the TURP using a digital clinical thermometer, which was inserted to the mouth ( \pm 3 minutes). At the conclusion of the procedure, a final temperature reading, using the same digital clinical thermometer was taken. The age, resection time, weight of resected prostate, amount of irrigating fluid used and temperature in the operating theatre were recorded.

By taking the power $(\beta)=0.8, \alpha=0.05$ and clinically significant of temperature difference of $1^{0} \mathrm{C}$, a total 16 samples is needed in each group. The test was used for comparison between groups. Correlation was performed for the analysis of the influence of resection time on body temperature. A p value of 0.05 or less was considered significant.

\section{RESULTS}

A total of 32 patients with mean age of $66,4 \pm 7,7$ years (range : $50-82$ years) were enrolled in this study. Standard group consisted of 16 patients (mean age $64,0 \pm 7,0$ years) and isothermic group consisted of 16 patients (mean age $68,8 \pm 7,8$ years).

Table 1 shows characteristics of patients undergoing TURP. No significant difference concerning age, resection time and amount of irrigating fluid between the two groups. The weight of resected prostate was significantly higher in standard group.

Table 1. Characteristics of patients undergoing TURP in standard group and isothermic group

\begin{tabular}{lccc}
\hline Variables & $\begin{array}{c}\text { Standard } \\
\text { Group } \\
(\mathrm{n}=16)\end{array}$ & $\begin{array}{c}\text { Isothermic } \\
\text { Group } \\
(\mathrm{n}=16)\end{array}$ & $\mathrm{p}$ \\
\hline Age (years) & $64,0 \pm 7,0$ & $68,8 \pm 7,8$ & 0.080 \\
$\begin{array}{l}\text { Resection time } \\
\text { (minutes) }\end{array}$ & $70,9 \pm 19,2$ & $69,4 \pm 14,8$ & 0.798 \\
$\begin{array}{l}\text { Weight of resected } \\
\text { prostate (g) }\end{array}$ & $22,7 \pm 6,8$ & $14,3 \pm 8,3$ & 0.004 \\
$\begin{array}{l}\text { Amount of } \\
\text { irrigating fluid }\end{array}$ & $24,8 \pm 6,4$ & $24,1 \pm 7,9$ & 0.759 \\
used (L) & & & \\
\hline
\end{tabular}

Table 2. Comparison of standard group and isothermic group based on temperature in the operating theatre, temperature of irrigating fluid, and core body temperature at beginning and conclusion of TURP

\begin{tabular}{lccc}
\hline Variables & $\begin{array}{c}\text { Standard } \\
\text { Group } \\
(\mathrm{n}=16)\end{array}$ & $\begin{array}{c}\text { Isothermic } \\
\text { Group } \\
(\mathrm{n}=16)\end{array}$ & $\mathrm{p}$ \\
\hline $\begin{array}{l}\text { Temperature in } \\
\text { the operating } \\
\text { theatre }\left({ }^{0} \mathrm{C}\right)\end{array}$ & $22.25 \pm 0.71$ & $22.16 \pm 0.35$ & 0.640 \\
$\begin{array}{l}\text { Temperature of } \\
\text { irrigating fluid } \\
\left({ }^{0} \mathrm{C}\right)\end{array}$ & $23.63 \pm 1.41$ & $37.16 \pm 0.30$ & 0.000 \\
$\begin{array}{l}\text { Core body tem- } \\
\text { perature before }\end{array}$ & $36.43 \pm 0.33$ & $36.53 \pm 0.36$ & 0.445 \\
$\begin{array}{l}\text { TURP }\left({ }^{0} \mathrm{C}\right) \\
\text { Core body } \\
\text { temperature after }\end{array}$ & $35.44 \pm 0.33$ & $35.78 \pm 0.37$ & 0.012 \\
TURP $\left({ }^{0} \mathrm{C}\right)$ & & & \\
\hline
\end{tabular}


The ambient temperature in the operating theatre for both groups was not significantly different $(\mathrm{p}=0.640)$. The mean temperature of irrigating fluid used by standard group was $23.63 \pm 1.41{ }^{\circ} \mathrm{C}$ and that used by isothermic group was $37.16 \pm 0.30{ }^{0} \mathrm{C}(\mathrm{p}=0.000)$.

No significant difference of basal core body temperature between the two groups. At the completion of procedure, however, the average temperature in standard group was significantly lower than that of isothermic group (Table 2).

Table 3. Comparison of the decrease in core body temperature at conclusion of TURP in standard group and isothermic group.

\begin{tabular}{lccc}
\hline & $\begin{array}{c}\text { Standard } \\
\text { Group }\end{array}$ & $\begin{array}{c}\text { Isothermic } \\
\text { Group }\end{array}$ & $\mathrm{p}$ \\
\hline $\begin{array}{l}\text { Decrease in core } \\
\text { body temperature } \\
\left({ }^{0} \mathrm{C}\right)\end{array}$ & $0.99 \pm 0.48$ & $0.75 \pm 0.36$ & \\
\hline
\end{tabular}

Table 4. Mean core body temperature at beginning and conclusion of TURP in standard group and isothermic group.

\begin{tabular}{lccc}
\hline & \multicolumn{2}{c}{ Core Body Temperature } & \multirow{2}{*}{$\mathrm{p}$} \\
\cline { 2 - 3 } & Before TURP & After TURP & \\
\hline Standard group & $36.43 \pm 0.33$ & $35.44 \pm 0.33$ & 0.000 \\
Isothermic group & $36.53 \pm 0.36$ & $35.78 \pm 0.37$ & 0.000 \\
\hline
\end{tabular}

Table 5. Correlation between resection time and core body temperature changes in both groups, standard group and isothermic group.

\begin{tabular}{lcccc}
\hline & $\begin{array}{c}\text { Resection time } \\
\text { (minutes) }\end{array}$ & $\begin{array}{c}\Delta \mathrm{t} \\
\left({ }^{0} \mathrm{C}\right)\end{array}$ & $\mathrm{r}$ & $\mathrm{p}$ \\
\hline Both groups & $70.16 \pm 16.87$ & $0.87 \pm 0.44$ & 0.295 & 0.101 \\
Standard group & $70.94 \pm 19.17$ & $0.99 \pm 0.48$ & 0.440 & 0.088 \\
Isothermic group & $69.38 \pm 14.82$ & $0.75 \pm 0.36$ & 0.044 & 0.873 \\
\hline
\end{tabular}

Table 3 shows that no significant difference was observed as regard to the decrease in core body temperature between standard group and isothermic group $(\mathrm{p}=0.125)$.

Table 4 shows that all of 16 patients who received room temperature irrigating fluid demonstrated a significant decrease of core body temperature $(\mathrm{p}=0.000)$.
The same condition was also occurred to all patients who received warmed irrigating fluid $(\mathrm{p}=0.000)$.

Decrease in core body temperature was not influenced by resection time as indicated by a weak correlation between resection time and body temperature changes in both groups, standard group and isothermic group ( $\mathrm{r}=0.295,0,440$ and 0.044 respectively). (Table 5).
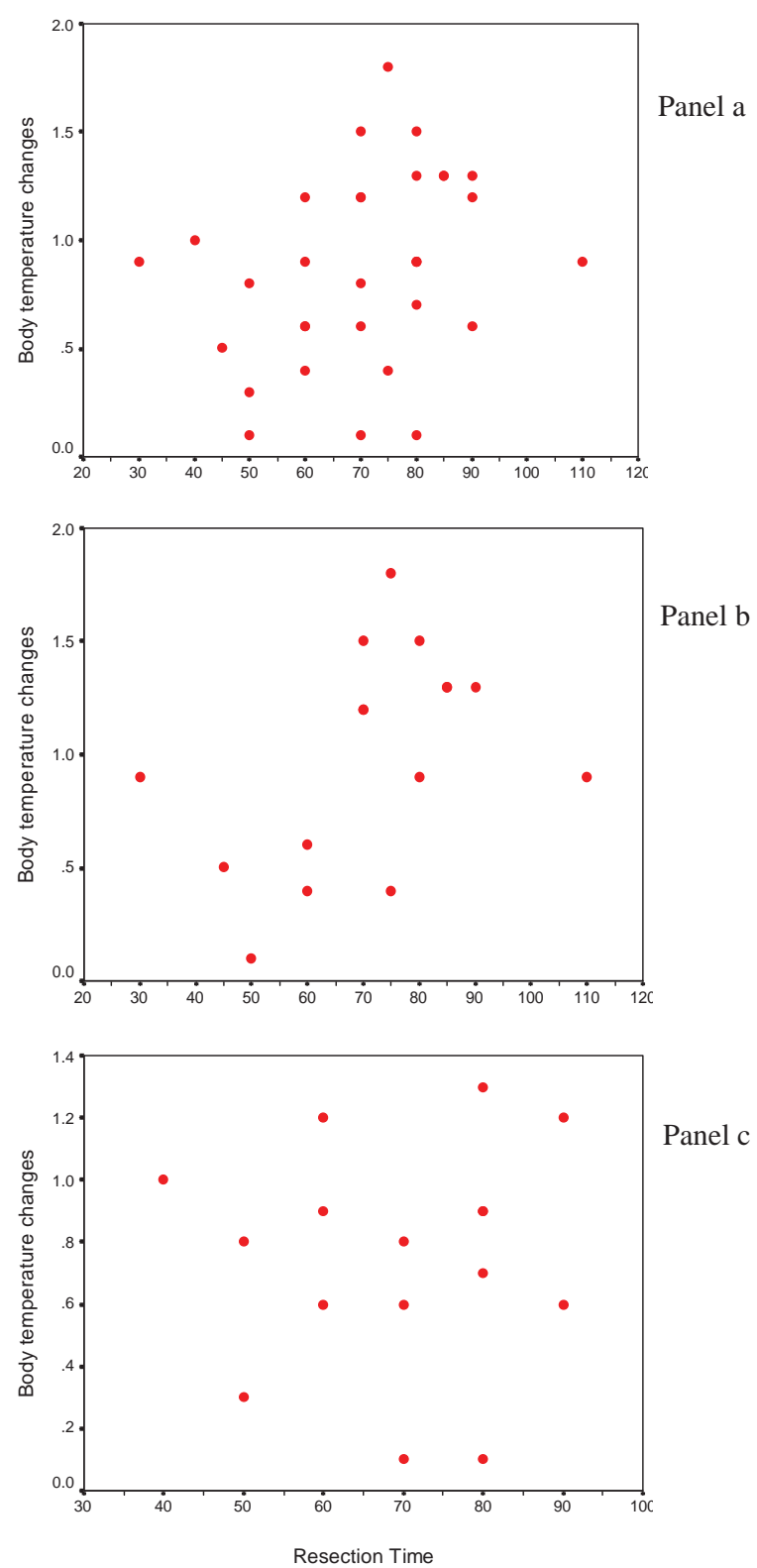

Figure 1. Correlation between resection time and body temperature changes in both groups (panel a), standard group (panel b), and isothermic group (panel c). 


\section{DISCUSSION}

A significant proportion of post TURP life threatening complications are cardiovascular in origin. Patients undergoing TURP are at risk for perioperative physiological disturbances related to the use of irrigating fluid and the surgical site, including hypothermia, irrigant overload, hemorrhage, sepsis, hypervolemia and hypovolemia. These disturbances are recognized as the source of cardiovascular stress causing arrhythmia, myocardial ischemia and heart failure. A decrease in cardiac output of $17.5 \%$ was reported in patients undergoing TURP. Changes in systemic vascular resistance and increased pulmonary artery wedge pressure were also identified in high risk patients undergoing TURP. ${ }^{2}$

Post TURP hypothermia has received little attention in the urologic literature. ${ }^{4}$ Hypothermia is defined as a decline in the core body temperature to less than $35^{\circ} \mathrm{C}$ $\left(95^{0} \mathrm{~F}\right)$, such that the coordinated system responsible for thermoregulation begin to fail because the compensatory physiologic responses to minimize heat loss are limited. Hypothermia can induce shivering, a homeostatic control in an attempt to regulate the core body temperature. However, shivering has been shown to increase oxygen demands by as much as $500 \%$. So, in patients with compromised cardiac function, this increase in oxygen demand may induce angina pectoris, myocardial infarction and arrhythmia. ${ }^{3}$ Hypothermia in the immediate post TURP period is associated with postoperative instability, prolonged recovery and increased risk of myocardial ischemia in the subsequent 24 hours. ${ }^{5}$

Monga et all ${ }^{5}$ suggested that body temperature decreased significantly in patients who underwent TURP with irrigating fluid at operating room temperature $\left(17{ }^{\circ} \mathrm{C}\right)$, but did not decrease in patients who received a continuously warmed irrigating fluid $\left(37{ }^{0} \mathrm{C}\right)$. This results indicate that a continuously warmed irrigating fluid could prevent the fall in body temperature during TURP, especially under spinal anaesthesia. ${ }^{5,6}$ Pit et all ${ }^{7}$ revealed that isothermic irrigating fluid during TURP prevented excessive cooling and reduced the risk of hypothermia. Ogura et all $^{8}$ demonstrated that the incidence of shivering and blood loss were lower in the warmed irrigating fluid group $\left(37{ }^{0} \mathrm{C}\right)$. The similar condition had also been shown by Carpenter ${ }^{4}$ and Dyer Heathcote ${ }^{9}$ (room temperature was $\pm 20^{\circ} \mathrm{C}$ ).
Another study which was conducted by Evans et all ${ }^{2}$ demonstrated that standard TURP patients (temperature of irrigating fluid was $21{ }^{\circ} \mathrm{C}$ ) exhibited rapid central cooling with significant hemodynamic responses, while isothermic TURP patients (irrigating fluid temperature $38{ }^{\circ} \mathrm{C}$ ) exhibited minor decreases in core body temperature with stable hemodynamic. Central cooling is caused by the use of unheated irrigant. Heat is lost 32 times faster into water than into air. Since the bladder is close to the body core, heat is transferred rapidly down the temperature gradient between the body core and the irrigant within the bladder. Rapid central cooling is inevitable when unheated irrigant is used. Hypothermia is a recognized cardiac stress and causes cardiovascular responses. Furthermore, hypothermia has a detrimental effects on all body systems and the stress of rewarming is poorly tolerated by patients with a limited cardiorespiratory reserve. ${ }^{2}$

This study revealed a decrease in core body temperature during TURP, either in standard group or in isothermic group (Both $p=0.000$ ), but none of the patients in either group demonstrated any criteria of hypothermia (core body temperature less than $35^{\circ} \mathrm{C}$ ). The average decrease of core body temperature in standard group $\left(0.99^{\circ} \mathrm{C}\right)$ was greater than in isothermic group $\left(0.75^{\circ} \mathrm{C}\right)$, but it was not significantly different $(\mathrm{p}$ $=0.125$ ). Actually, there was a clear tendency of body temperature decrease in standard group. However, the difference did not reach statistical significance, which is probably due to small sample size. So, although the decrease was not significantly different, but absolute body temperatures after TURP were significantly different.

On the other hand, Jaffe et all ${ }^{3}$ suggested that irrigating fluid temperature was not a factor responsible for altering the core body temperature in patients undergoing TURP. Factors such as the length of time spent in the operating room and ambient temperature, along with the resection time and the amount of irrigating fluid absorbed, may have a greater impact on the core body temperature than the irrigating fluid temperature. This idea was supported by Hahn ${ }^{10}$ who concluded that absorption of irrigating fluid was a mechanism that promotes heat loss during transurethral operations.

In this study, factors which might influence core body temperature changes during TURP were recorded. Age of patients, resection time, total volume of irrigating fluid, temperature of operating theatre and core body 
temperature at beginning of TURP either in standard group or in isothermic group were not significantly different. These circumstances supported the aim of the study by controlling other variables which might have influences.

The result of this study also demonstrated that a decrease in core body temperature was not influenced by resection time. Correlation between resection time and body temperature changes in both groups, standard group and isothemic groups are weak. This condition is similar to the result of Monga's study, which concluded that resection time had no influence on core body temperature changes during TURP. ${ }^{5}$

It is concluded that using either room temperature or warmed irrigating fluid during TURP could decrease core body temperature at approximately similar level, but there was a significant difference in final body temperature in both groups. However, the decrease of core body temperature did not fall into hypothermic state, so that using room temperature irrigating fluid $\left( \pm 23{ }^{0} \mathrm{C}\right)$ in our hospital setting, is considered safe.

\section{REFERENCES}

1. Fitzpatrick JM, Mebust WK. Minimally invasive and endoscopic management of benign prostatic hyperplasia.
In : Walsh PC, ed. Campbell's Urology. Philadelphia: Saunders, 2002;1379-422.

2. Evans JWH, Singer M, Coppinger SWV, Macartney N, Walker JM, Milroy EJG. Cardiovascular performance and core temperature during transurethral prostatectomy. J Urol 1994; 152:2025-9.

3. Jaffe JS, McCullough TC, Harkaway RC, Ginsberg PC. Effects of irrigating fluid temperature on core body temperature during transurethral resection of the prostate. Urology 2001; 57(6):1078-81.

4. Carpenter AA. Hypothermia during transurethral resection of prostate. Urology 1984; 23(2):122-4.

5. Monga M, Comeaux B, Roberts JA. Effect of irrigating fluid on perioperative temperature regulation during transurethral prostatectomy. Eur Urol 1996; 29(1):26-8.

6. Harioka T, Murakawa M, Noda J, Mori K. Effect of continuously warmed irrigating solution during transurethral resection. Anaesth Intens Care 1988; 16(3):324-8.

7. Pit MJ, Tegelaar RJ, Venema PL. Isothermic irrigating during transurethral resection of the prostate: effects on peri-operative hypothermia, blood loss, resection time and patient saticfaction. Br J Urol 1996; 78(1):99-103.

8. Ogura K, Fukuyama T, Nakagawa K. The effects of warm irrigating fluid during and after transurethral prostatectomy. Clin Ther 1988; 10:20-1.

9. Dyer PM, Heathcote PS. Reduction of heat loss during transurethral resection of the prostate. Anaesth Intens Care 1986; 14:12-6.

10. Hahn RG. Cooling effect from absorption of prewarmed irrigating fluid in transurethral prostatic resection. Int Urol Nephrol 1993; 25(3):265-70. 